\title{
“Last Kilometer" Distribution Strategy Research of the County Logistics
}

\author{
Zhimin Guo, Peijia Guo, Wenyi Zhao, Jiani Wu, Huiling Xiao, Qing Liang, Qingming Zou \\ School of Economics \& Management, University of South China, Hengyang, China \\ Email: zhimin.g@yahoo.com
}

How to cite this paper: Guo, Z.M., Guo, P.J., Zhao, W.Y., Wu, J.N., Xiao, H.L., Liang, Q. and Zou, Q.M. (2017) "Last Kilometer" Distribution Strategy Research of the County Logistics. Open Journal of Social Sciences, 5, 251-262.

https://doi.org/10.4236/jss.2017.55018

Received: April 12, 2017

Accepted: May 20, 2017

Published: May 23, 2017

Copyright $\odot 2017$ by authors and Scientific Research Publishing Inc. This work is licensed under the Creative Commons Attribution International License (CC BY 4.0).

http://creativecommons.org/licenses/by/4.0/

\begin{abstract}
With the rapid development of e-commerce, the rural e-commerce also has gained great progress. The scale of the county logistics is also broadened. However, as the end of the logistics service chain directly linked with the customer, the "last kilometer" distribution strategy has become a bottleneck in the development of the county logistics. By analyzing the present situation and existed problems of the county logistics distribution, this paper explores main factors working on rural e-commerce distribution, and based on which it proposes "the last kilometer" distribution strategy of the county logistics.
\end{abstract}

\section{Keywords}

Last Kilometer, Distribution, E-Commerce

\section{Introduction}

In recent years, e-commerce has been developing rapidly and gradually pushed from the city market to the rural market. Rural e-commerce has become one of the key factors in the whole e-commerce. It also promotes the development of regional economy. The continuous expansion of e-commerce trading directly affects the further development of the logistics industry. E-commerce logistics is different from other logistics; its timeliness of delivery, service quality and information traceability of goods relative to the demand are higher. But in the real life, objective environment has led varieties of difficulties for goods' delivery work. It is directly related to final customers, which also has caused the problem of logistics distribution of the "last kilometer". The "last kilometer" is also called the last mile; it means the last leg of a long journey [1]. In extension, the "last kilometer" refers to the distance among the distribution center, the dispersal center, and the customer. "Last kilometer" is the last step of the logistics distribution, which can implement the door to door delivery; it is very convenient for 
users, and the customers' satisfaction will be improved, thereby expanding the advantages of the customer base. In rural areas, because of the special social and economic conditions, the e-commerce distribution of the "last kilometer" has become a bottleneck in the county rural logistics development.

The problem of the "last kilometer" has effect on the logistics to move on; many studies about how to solve it have put forward some strategies and advice. Ehmke and Campbell noted [2] that goods distribution mode is a key factor for restricting the development of e-commerce retail. And through the development of home delivery mechanism, it can maximize the logistics service, improve customer satisfaction, attract more customers and bring more profits. Based on the hierarchy analysis model, Aized T. and Srai [3] constructed the "last kilometer" distribution system, and they used Petri to solve the congestion problem in distribution. Zhang Jin [4] thought that the plight of the "last kilometer" includes not only the end of the distribution problem, but also upstream and downstream interface, such as the path optimization problem, Pei Zailv, choice of transport problems, and improved customer service quality problems. Yang Juping [5] did feature extraction and cluster analysis for electricity customers, then he proposed to build public electronic container, artificial self-help container and door-to-door distribution scheme to solve the problem of "the last kilometer" e-commerce distribution. After studying the "Internet +" and the "last kilometer" of distribution situation, Zhan Bin [6] put forward some innovative ideas, such as establishing visual distribution service, evaluation of the express business functions, cooperation from the cabinet, UAV Express and so on. The "last kilometer" of study to the literature on urban logistics as an object was not involved in the study of county rural logistics, and did not reach the last mile of rural e-commerce.

In this paper, the electricity business environment as the object, problems of the rural logistics last mile on the basis of the traffic inconvenience, distribution sites scattered characteristics, analyze county logistics current situation and influencing factors, put forward the strategies of the last mile crack rural logistics problems, help the county logistics and the development of county economy, break the dual structure between urban and rural, promote the development of urban and rural integration.

\section{The Present Development Status of "Last Kilometer" in County Logistics}

The "last kilometer" appears under the background that the logistics industry can hardly catch up with the rapid development of Electronic-Commerce. "Last kilometer" is the last and the most important step during the distribution activity. County residents living too scattered lead to the high cost of delivery at the end of the distribution and the lower customer satisfaction, so "last kilometer" turns to be more challenging.

According to the data from <analysis report of market prospect \& investment strategy planning on china express delivery industry (2016-2021) of the prospec- 
tive industry institution, the coverage of express site is only $48 \%$ in villages and towns by 2015 [7], which makes negative effect on the speed of logistics and development of Electronic-Commerce in country. Although many logistics enterprise make effort to build infrastructures, construct logistics network, increase logistics site, for example, the rookie logistics, which has achieved delivery to village in more than 1200 villages, but there are only $20 \%$ goods for order could be delivered the same day or the next day [8]. At the same time, the quantity of complaints of express service is always a huge number, the state post bureau published the major compliments and the ratio of these compliments, such as compliments in December 2016.

From the above Table 1, we can see that the main problem with consumers complaints on the courier service compared with last month are on the rise. Among them, the delay, the lack of missing problems increased significantly, an increase of $107.6 \%$ and $101.3 \%$ respectively. Compared to the same period last year, the main problems of courier services have declined. The focus of the complaint is the delivery of services and delays, accounting for $36.5 \%$ and $33.7 \%$, respectively. For the express company, customer complaints are an important problem that they have to face.

From the above Table 2, we can see that in December 2016 the national express service effective complaint rate is $12.68 \%$, and the link relative increased by $6.36 \%$, the chain relative dropped by $22.02 \%$. There are 11 express company effective complaint rates are higher than the national average. The table above shows that, with the development of logistics, especially the increase of township business, there are some problems in the logistics distribution gradually increased, and has affected the promotion of regional logistics, therefore, it's very necessary to find that the influence factors of logistics distribution, and take corresponding measures to improve the efficiency and quality of logistics distribution service for enterprises and society.

Table 1. The main issues and proportion of consumer complaint delivery services in December 2016.

\begin{tabular}{cccccc}
\hline $\begin{array}{c}\text { Sequence } \\
\text { number }\end{array}$ & Compliment & $\begin{array}{c}\text { Number of } \\
\text { compliment }\end{array}$ & Proportion\% & $\begin{array}{c}\text { Link relative } \\
\text { growth\% }\end{array}$ & $\begin{array}{c}\text { Chain relative } \\
\text { growth\% }\end{array}$ \\
\hline 1 & delay & 15695 & 36.5 & 107.6 & -59.1 \\
2 & Delivery service & 14515 & 33.7 & 63.2 & -44.3 \\
3 & Missing or shortage & 8673 & 20.1 & 101.3 & -36.2 \\
4 & damaging & 2890 & 6.7 & 44.8 & -21.1 \\
5 & Receiving service & 842 & 2.0 & 26.8 & -37.5 \\
6 & Illegal charge & 202 & 0.5 & 16.8 & -47.4 \\
7 & Collecting money & 104 & 0.2 & 5.1 & -44.1 \\
8 & other & 122 & 0.3 & 32.6 & -55.0 \\
9 & total & 43044 & 100.0 & 81.0 & -48.7
\end{tabular}

(Note: Notice of the State Post Bureau on consumer complaints in the post office in December 2016). 
Table 2. The effective complaint rate for major express delivery companies in December 2016.

\begin{tabular}{|c|c|c|c|c|c|c|}
\hline \multirow{2}{*}{$\begin{array}{l}\text { Enterprise } \\
\text { name }\end{array}$} & \multirow{2}{*}{$\begin{array}{c}\text { The effective } \\
\text { complaint rate } \\
\text { in December } \\
2016\end{array}$} & \multicolumn{3}{|c|}{$\begin{array}{l}\text { The effective complaint rate about the } \\
\text { main problem }\end{array}$} & \multirow{2}{*}{$\begin{array}{c}\text { The effective } \\
\text { complaint rate in } \\
\text { December } 2015\end{array}$} & \multirow{2}{*}{$\begin{array}{l}\text { The same } \\
\text { percentage }\end{array}$} \\
\hline & & Delay & $\begin{array}{l}\text { Missing or } \\
\text { damaging }\end{array}$ & $\begin{array}{c}\text { Delivery } \\
\text { service }\end{array}$ & & \\
\hline Rufengda & 66.85 & 26.96 & 22.50 & 15.74 & 45.69 & $\uparrow$ \\
\hline Guotong & 52.86 & 28.77 & 8.69 & 14.38 & 44.79 & $\uparrow$ \\
\hline ZJS Express & 34.24 & 12.46 & 7.92 & 12.74 & 40.23 & $\downarrow$ \\
\hline $\begin{array}{c}\text { STO } \\
\text { Express }\end{array}$ & 31.41 & 12.45 & 8.07 & 10.24 & 55.01 & $\downarrow$ \\
\hline TTK Express & 22.51 & 9.89 & 5.76 & 6.27 & 59.49 & $\downarrow$ \\
\hline Quanfeng & 21.17 & 7.57 & 6.60 & 6.33 & 65.65 & $\downarrow$ \\
\hline $\begin{array}{l}\text { Deppon } \\
\text { Express }\end{array}$ & 19.26 & 9.12 & 4.19 & 5.41 & 4.39 & $\uparrow$ \\
\hline UC Express & 16.86 & 4.54 & 4.16 & 7.57 & 20.60 & $\downarrow$ \\
\hline Amazon & 13.97 & 7.98 & 0.00 & 5.99 & 1.66 & $\uparrow$ \\
\hline UPS & 13.46 & 6.53 & 2.04 & 4.89 & 9.47 & $\uparrow$ \\
\hline YTO Express & 13.31 & 3.18 & 4.57 & 5.19 & 47.08 & $\downarrow$ \\
\hline Sure Express & 9.98 & 2.92 & 2.84 & 3.93 & 10.68 & $\downarrow$ \\
\hline $\begin{array}{c}\text { China Air } \\
\text { Express }\end{array}$ & 9.91 & 1.24 & 2.48 & 6.20 & 4.82 & $\uparrow$ \\
\hline TNT & 9.48 & 1.18 & 4.74 & 1.18 & 1.30 & $\uparrow$ \\
\hline EMS & 9.31 & 3.86 & 2.34 & 2.77 & 17.43 & $\downarrow$ \\
\hline $\begin{array}{c}\text { ZTO } \\
\text { EXPRESS }\end{array}$ & 9.12 & 2.81 & 2.18 & 3.79 & 27.45 & $\downarrow$ \\
\hline HTKY & 7.89 & 2.08 & 2.88 & 2.67 & 32.61 & $\downarrow$ \\
\hline $\begin{array}{c}\text { FAST } \\
\text { EXPRESS }\end{array}$ & 6.84 & 2.43 & 1.96 & 2.24 & 33.09 & $\downarrow$ \\
\hline Unitop & 5.51 & 0.83 & 2.75 & 1.65 & 8.59 & $\downarrow$ \\
\hline $\begin{array}{l}\text { YunDa } \\
\text { Express }\end{array}$ & 3.95 & 0.81 & 1.18 & 1.81 & 60.59 & $\downarrow$ \\
\hline DHL & 3.10 & 0.52 & 0.52 & 1.81 & 2.90 & $\uparrow$ \\
\hline FedEx & 2.88 & 1.28 & 0.64 & 0.32 & 1.69 & $\uparrow$ \\
\hline 4PX EXPRESS & 2.33 & 0.78 & 0.48 & 1.07 & 5.61 & $\downarrow$ \\
\hline SF Express & 2.18 & 0.82 & 0.56 & 0.59 & 3.78 & $\downarrow$ \\
\hline JD.CON & 1.09 & 0.24 & 0.31 & 0.49 & 2.09 & $\downarrow$ \\
\hline Suning & 0.05 & 0.05 & 0.00 & 0.00 & 7.39 & $\downarrow$ \\
\hline total & 12.68 & 4.62 & 3.41 & 4.27 & 34.70 & $\downarrow$ \\
\hline
\end{tabular}

Unit: a valid appeal/millions of pieces of courier.

From the domestic and foreign logistics experience, taking into account the characteristics of the vast majority of China's County logistics. Based on the enterprise and government as the object, we put forward some strategies to solve the "last mile" logistics which aim to boost the development of county logistics, 
break the dual structure between urban and rural, and promote the development of urban and rural integration.

In this paper, through the field investigation in the country, according to the characteristics of county logistics and the development of social economy, we find that the factors that restrict the development of "last kilometer" and the supporting development of rural Electronic-Commerce are various. It comes down to three aspects: enterprise, employee and social economy.

\subsection{The Factor of Enterprise}

National bureau of statistics show that county area is spacious while researchers relatively scattered, and the logistics infrastructure relatively falls behind. To improve the last kilometer Distribution, logistics enterprise investment and cooperation are needed, in reality, however, there has many problems.

1) Low degree of enterprise value

The form of enterprises to enter the county is simple but expensive, and it also doesn't meet the demand for the development of rural logistics now. At present, many express still focus on the overall logistics transportation, the pursuit only stay at the level of the delivery of object. In the reconstruction of county logistics infrastructure, the great invested capital and a long construction period make some small Courier company don't want to spend too much energy on the "last kilometer" problem with money.

2) Logistics resources repetition

At present, China's express delivery industry has more than 8000 enterprises, different brand express tend to delivery respectively in the same place, this makes express delivery efficiency is low, increases the delivery cost of a single Courier company, causes the waste of vehicles personnel resource. After the package arriving at the city and resorting, the speed of the delivery began to slow down, this makes the orders that customers can check not match with the actual progress of logistics. Logistics resources repetition largely increase the time of logistics distribution at the last kilometer, this is also an important cause of the highest delay claims.

3) The backward Enterprise terminal distribution way

At present, the logistics enterprise terminal distribution are mainly rely on the electric tricycle and van, lack of corresponding protection, which is easy to increase the rate of the damage to the goods, and sorting is still mainly rely on artificial fill in the form, reading information of goods, manual handling cargo. The lack of corresponding informatization and mechanization will seriously affect punctuality and cargo damage rate of delivery at the "last kilometer".

\subsection{The Factor of Staff}

The less developed County economy, the inconvenient in life, logistics enterprise employee's lack of work quality, working attitude and service consciousness also affect the logistics distribution work.

1) Enterprise employees to the countryside enthusiasm is not high 
Employees to the countryside, easy for dialect different living habits, it is difficult to blend in to the local people, regardless to say, to really solve the practical problems of logistics enterprises. In order to solve the above problem, more enterprises adopt the method of recruit workers from local, however, this part of the staff did not have enough management experience, can only be engaged in simple Courier transceiver, unable to further expansion of enterprises in the development of the county

2) Frequent work service problems

The statistics of State Post Bureau show that the effective complaints of users about the express service have 43,044 cases rose $81.0 \%$ from the last year, it explains that direct communication link between the termination and consumers remains barriers. When Couriers sending the packages, they tend to follow the habit of outdated don't send and some customers due to other reasons such as work and missed the pick-up time, this leads to the goods cannot be delivered to the customer in time. Quite a number of Couriers tend to express with throw, do not pay attention to the storage of items, which can lead to lower customer satisfaction. Courier service attitude is poor, does not pay attention to the communication with customers and customer relationship maintenance, all this will potentially influence on the quality of distribution terminal people satisfaction.

\subsection{Socioeconomic Factors}

The distribution of the last mile of the county logistics is closely related to the local social and economic conditions, and the factors such as population size, aggregation, transportation convenience and per capita income affect the efficiency of logistics distribution.

1) The problem of rural residential scale

The rural area is vast, the distance between the village and the village, between households and households is different, so that there is no scale formation. Thus three situations occurred: 1) distribution staffs often choose to accumulate a certain amount of express and then sent to the village, which aims to avoid high delivery cost back and forth, resulted in slow logistics delivery period. 2) Distribution staffs went to multiple villages back and forth, which is easy to lose courier items. 3) Staffs did not provide door-to-door service; customers have no choice but to pick up express, wade a few kilometers from mentioning the goods. If things go on like this, customers will easily have a low shopping frequency, and choose to go shopping at store.

2) Rural residents are weak in the use of online shopping and logistics

According to the research, it shows that there is a greater correlation between the logistics needs and the age of the residents. The more young people live in the community, the bigger demand of online shopping. The elderly and children in the mainstream of the village is less demand for online shopping. By 2015, the elderly left behind in rural areas accounted for $37 \%$ of the elderly population in rural areas. In addition, the rural residents have a lower level of education, their learning ability and the ability to operate the network is weak, leading to the 
long period of online shopping reception. In addition, the rural residents have a strong sense of thrifty; they did not change the impression of online shopping. In their view, online shopping is considered equal to spend money, which is the direct cause that some people refuse to buy goods online.

3) Low transport network density

The overall scale of transportation infrastructure in China is still very small. According to the National Bureau of statistics data, by 2015, the transport network density counted by the number of land area and population, China is only 1344.48 kilometers per million square kilometers and 10.43 kilometers per million people, while the United States is 6869.3 kilometers/square kilometers and $1253.59 / \mathrm{km}$ million people, Our country is far behind Europe and the United states. It would be a more serious problem if China still weak in the transport network density, especially for the county. The low penetration rate and poor infrastructure have become key constraints that affect County logistics last mile distribution.

\section{The "Last Kilometer" Distribution Strategy of County Logistics}

The "last kilometer" distribution of county logistics is restricted by three aspects, enterprises, employees and social economy. Therefore, this article draws lessons from the domestic and foreign mature logistics distribution plan, combined with the characteristics of county logistics. According to research the county area's characteristics about economically underdeveloped, and poor infrastructure. Finally, we puts forward the "last kilometer" of the county logistics strategy.

\subsection{International Reference of the Last Mile Logistics}

Foreigners are aware of the "last kilometer" logistics distribution problem already, and many effective solutions are proposed. Mainly focus on logistics infrastructure construction and system optimization. In Japan, retail stores all over the country, 7 - 11 convenience store is very representative. At present, 7 - 11 convenience store has developed into a Japanese express access site. In Germany, customers mainly depend on advanced technology to carry out self-service parts. In Canada, the electricity supplier logistics company BufferBox establishes cooperation relationship with retailers and express logistics enterprises. The user receives a package from the surrounding retailer by obtaining the only password for the package.

\subsection{Domestic Solutions}

Some logistics enterprises to learn from the experience of successful cases abroad, introduce the model and localization innovation. The solution to the last mile distribution problem of urban logistics is put forward.

1) The emergence of the proposed model

At present, our country has already begun to develop self-service model, most cities have emerged self-service delivery machine. But the self-service pick up 
machine is more suitable for the large-scale community use. For the county or village, those scattered settlements, the use efficiency of self-service delivery machine will be greatly reduced; distribution distance is still a problem. It is even more difficult to maintain the self-service delivery machine.

2) Establish city alliance

In order to solve the problem of insufficient resources, enterprises choose to form Logistics Alliance, such as the rookie network. Alibaba group, in-time group joint Fosun Group, Fuchun holdings, SF group, Zhaijisong, Huitong, and related financial institutions established the Rookie network together. This large alliance includes logistics companies, financial companies, and electricity supplier enterprise. Collection goods, capital and logistics resources so that the last mile problem can be better solved. But until 2016, rookie logistics can only solve some rural distribution problems, rural economic backwardness and traffic inconvenience and other factors still restrict the development of rookie logistics in the county.

3) Develop of the contract joining mode

In the face of the "last kilometer" problem, enterprises often take the way: contractor to join. This is the main solution of the current courier companyexpanding the market relying on the network and constantly increasing business coverage. The establishment of the expressage is a new attempt for the courier companies to replace fixed-point delivery with mobile delivery. The rookie logistics choose to set up rookie inn as a collection of the brand expression delivery station, so that customers take more time to pick up. Over investigation, rookie logistics in the country has built a total of 25,000 rookie station [9].

\subsection{The "Last Kilometer" Solution Strategy of the County Logistics}

Based on the experience of domestic and foreign logistics and distribution, taking into account the characteristics of the vast majority of county logistics in China, we take the enterprise and the government as the object, and then put forward some strategies to solve the "last kilometer" of county logistics to boost the development of county logistics, to break the dual structure between urban and rural, and promote the development of urban and rural integration.

\subsubsection{For Enterprises}

A) Improve the logistics personnel quality and ability

Because of the characteristic of the county logistics cargo road far less, good employees are not willing to work in the countryside. Rural logistics staff of professional and business ability is generally low, so that influence the efficiency of logistics distribution. Combining with the characteristics of the above, we will suggest the following three aspects.

1) Change the concept of county logistics personnel to work in rural

Nowadays, because of low wages and less work opportunities for advancement, many college graduates don't want to work in rural areas. In order to solve these problems, Enterprises should improve the salary, such as setting up good post allowance to attract more outstanding personnel to go to work in the rural. 
In addition, the enterprise human resource managers should improve the performance evaluation mechanism. At the end of year, they should hold a fair and just attitude to take performance appraisal, and give good performance staff promotion, so as to solve the problem of talent go to the rural work hard.

2) Improve the quality and ability of the county logistics personnel

County logistics personnel quality and ability will influence the efficiency of goods distribution, logistics processing timeliness and integrity, and customer satisfaction for express service. For improving staff ability and accomplishment, many enterprises in China have created a lot of referential measures. For instance, telecom companies tend to cooperate with some universities and open the direct "telecom class". When they graduate, they have the direct opportunity to work in the telecom enterprise. For logistics enterprises, especially large logistics enterprises, they cooperate with universities to set up "logistics class", and cultivate professional talents for the logistics company. In addition, the enterprise also can engage some professional university teachers at regular intervals to teach the enterprise staff, for improving the staff's logistics specialty accomplishment.

3) Employee recruitment methods innovation

Companies can change the point of blindly recruiting talented people, and try on the recruitment of local staff. For the local recruitment of staff, you can use the $t$ generous treatment to attract young local people, and give full play of the advantages in their familiarization with the local residents and traffic conditions to get a faster and better delivery. Residents are familiar with each other, so the local recruited employees are easy to have a trust, and increase customer satisfaction. In addition, training systematically part-time young people and then going to work, this can effectively save costs and enhance customer experience in the logistics experience.

B) Innovative operation mode

1) To build distribution alliance

County logistics related to the vast rural areas, where the amount of goods is less. And logistics enterprises rely on the enterprise's human and transport to bear the task of distribution with higher cost, affecting their efficiency. But with the same region of different enterprises to complete the distribution business together, can save resources and enhance business performance. Therefore, to build county logistics and distribution alliance is conducive to the integration of resources and the "last kilometer" problem solving.

Logistics alliance in China has begun a small number of enterprises pilot, but its effect is not significant enough. Currently the hidden alliance, such as the alliance between Shun Feng and Yuan Tong, is the most common to see. When the accessories lacked or distribution distance is far long, practitioners of SF and Yuan Tong will exchange express each other, and complete the distribution target separately. But this model mainly exists in the absence of conflicts of interest between enterprises, but due to considerations of establishing brand, some companies are not willing to take this model. The government issued a relevant 
document to encourage the courier industry city alliance, providing preferential measures will be able to make the problem improved to some degree. For the county logistics and distribution, it should build city alliance not only in logistics enterprises, but also with some car passenger service enterprises and part of the rural small shops, transport goods from some remote areas bus to the nearest rural distribution point through the daily passenger coach.

2) To enhance the real-time tracking of objects

The characteristics of the county logistics resulted in courier objects cannot reach customers in a timely manner, affecting customer satisfaction and corporate reputation, therefore, to strengthen the real-time tracking of objects on the county logistics and distribution is very important. At present, Yi Xun has launched the new function of "real-time tracking of the package location" in the mobile client, so that users can see the real-time location on the map, which help users to grasp time of the parcel delivery better. The final key of real-time tracking of logistics and distribution in county logistics is not yet universal, the logistics enterprises can grasp the point as the breakout to establish the logistics enterprise information system with county characteristics, and increase the application of bar code technology, EDI, RFID, GIS, GPS and other modern logistics information technology in all respects of the county logistics, to solve the timely and accurate issues of the "last kilometer" distribution.

\subsubsection{For Government}

1) To build rural electricity service center

Most of the rural areas in China have the tradition to go to the market, generally to speak, the interval is not long. And rural residents will be in a few surrounding markets to purchase materials. The "last kilometer" distribution of county logistics business should take full advantage of this convenience, setting up the express logistics agent points in designated retail shopping malls in the downtown and villages. The distribution personnel of logistics enterprise should fully understand the requirements of customer pickup, with the goods putting on the designated agent point. Through the rural e-commerce business service point setting up in the township market, you can achieve the more extensive coverage of the "last kilometer" in county logistics. So that the terminal of the county logistics delivery can implement a small range of transport and improve delivery efficiency.

Even in more remote villages, the villagers can also sell the city's consumer goods to rural areas through the rural e-commerce service center. The local farmers provide consumer goods purchasing, realizing agricultural resources to the countryside, while the farmers surplus agricultural products sold to the city, driving the development of rural related industries.

2) Strengthen rural logistics business propaganda efforts

County electricity business not only is an one-way online shopping courier, but also shoulder the sale of agricultural products. For the issue that rural residents unfamiliar with the electrical business and not good at using modern information technology to purchase and sale, companies need to increase publici- 
ty, so that the majority of rural residents know the power of all the convenience, thus increasing the amount of logistics and distribution and improving the "last mile" distribution efficiency. At the same time in the delivery of goods, though the dispatcher send leaflets along the way, send the product demand information and the way of online purchase and sale to the hands of rural residents; in the goods store and rural shops, post e-commerce propaganda; Enterprises can paint the advertises in the wall to carry out large-scale publicity and enhance the popularity of rural electricity business.

3) Give appropriate subsidies to the county logistics enterprises

For enterprises, the government should give appropriate subsidies to encourage them to improve the terminal distribution's transport vehicles of the "last kilometer" in county logistics, phasing out the more backward means of transport. For the imperfect problem of rural roads, on the one hand, the government can provide appropriate transport subsidies for the enterprises, reduce the cost of business to the countryside in improving the rural infrastructure construction premise. In addition, the government should encourage enterprises to introduce modern information technology, promote new technologies and equipment to replace the traditional manual operation, reduce cargo damage rate and improve work efficiency. Regarding to the problem of staff employees going to the countryside, the government can give them appropriate subsidies to encourage and actively introduce high-quality logistics personnel into the countryside, which will play a key role in building sound and rapid development of county logistics.

4) Improve the rural infrastructure

Infrastructure is the establishment of the production department directly and is the basis and precondition of the development. The rural poor, network infrastructure incomplete, the weak signal will directly hindered the development of county logistics in our country. Therefore, the government should take to increase the rural road construction and expansion of network infrastructure to improve rural infrastructure, and solve county logistics "the last kilometer" problem.

\section{Conclusions}

This paper analyzes the distribution of the County Logistics "last kilometer" problem, which can be attributed to three factors: enterprise factor, employee factor and social economic factor. Then, some strategies are put forward to solve the "last kilometer" problem of county logistics: to build distribution alliance, to develop self-mentioned mode, to strengthen real-time monitoring of objects, to enhance the quality of logistics personnel and increase propaganda or appropriate subsidies.

In this paper, the research results on the one hand can provide theoretical support and practical guidance for our country formulating regional logistics development policy, cultivate the logistics industry; on the other hand it also can provide theoretical basis for logistics enterprises to optimize operation; the logistics enterprise gradually fixes the existing problems, and builds efficient 
county logistics system to provide decision basis. And it also can boost the development of county logistics, break the dual structure between urban and rural, and promote the development of urban and rural integration.

The "last kilometer" of the logistics services is the last step of the electricity business courier; therefore, about how to effectively improve the logistics distribution's speed and quality, we need a deeper study and discussion. This paper qualitatively analyzes the influencing factors of "last kilometer" which affects the county logistics. In later research, the influencing factors can be quantitatively analyzed by using the data obtained from the survey, and the mathematical model will be used to find the optimal distribution path.

\section{Project}

College students' inquiry learning and innovative experimental project $342, \mathrm{Hu}-$ nan province of China.

\section{References}

[1] Gao, T. and Guo, D. (2004) China Circulation Industry Development Report. China Social Science Publishing, Beijing, 502-506.

[2] Ehmke, J.F. and Campbell, A.M. (2014) Customer Acceptance Mechanisms for Home Deliveries in Metropolitan Areas. European Journal of Operational Research, 233, 193-207.

[3] Aized, T. and Srai, J. (2014) Hierarchical Modeling of Last Mile Logistic Distribution System. The International Journal of Advanced Manufacturing Technology, 70, 1053-1061. https://doi.org/10.1007/s00170-013-5349-3

[4] Zhang, J. and Chen, Y. (2015) A Summary of the Research on "Last Kilometer" Problem in Logistics. China Circulation Economy, No. 4, 23-30.

[5] Yang, J., Yang, C. and Yao, X. (2014) A Study on the Problem of "Last Kilometer" in Electric Merchant Logistics. Commercial Economics and Management, No. 4, 16-22.

[6] Zhan, B., Gu, Z. and Li, Y. (2016) "Internet +" under the Background of Electricity Business Logistics "Last Kilometer" Distribution Model Optimization Research. Research and Discussion, No. 35, 4.

[7] Xu, Y. (2016) Research on the "Last Mile" Information System of Rural Logistics. Science and Technology Information, No. 4, 19-21.

[8] Xing, Y. (2015) Study on Strategies of Customer-Oriented Distribution Mode Concerning Last Mile Problem under E-Commerce Background. Research and Discussion, No. 4, 85-88.

[9] Xiao, J., Dong, Q. and Hao, S. (2017) Study on the Development of Rural Rookie Logistics. Commercial Economics, No. 1, 59-61. 
Submit or recommend next manuscript to SCIRP and we will provide best service for you:

Accepting pre-submission inquiries through Email, Facebook, LinkedIn, Twitter, etc. A wide selection of journals (inclusive of 9 subjects, more than 200 journals)

Providing 24-hour high-quality service

User-friendly online submission system

Fair and swift peer-review system

Efficient typesetting and proofreading procedure

Display of the result of downloads and visits, as well as the number of cited articles Maximum dissemination of your research work

Submit your manuscript at: http://papersubmission.scirp.org/

Or contact jss@scirp.org 